\title{
Clinical, Radiological and Histopathological Features of Patients With Lacrimal Gland Enlargement
}

\author{
Mansooreh Jamshidian Tehrani, MD; Esmaeil Asadi Khameneh, MD¹; Seyedeh Zahra Pourseyed lazarjani, MD; Hadi Ghadimi,
} $\mathrm{MD}^{1}$; Zohreh Nozarian, $\mathrm{MD}^{2}$; Maral Mokhtari, MD, APCP3*

'Department of Plastic and Reconstructive Surgery, Farabi Eye Hospital, Tehran University of Medical Sciences, Tehran, Iran ${ }^{2}$ Department of Pathology, Tehran University of Medical Sciences, Tehran, Iran

${ }^{3}$ Department of Pathology, Shiraz University of Medical Sciences, Shiraz, Iran

\begin{abstract}
Background: The purpose of this study was to describe the radiologic and histopathologic features of lacrimal gland in patients presenting with lacrimal gland enlargement.

Methods: We retrospectively retrieved the data of patients with lacrimal gland enlargement in Farabi Eye Hospital between 2012 and 2017. These data included demographics, the patients' facial photographs, orbital CT-scans, and histopathological findings of lacrimal gland biopsies.

Results: Forty-seven patients (15 men and 32 women) were enrolled in this study with a median age of 37.9 years (range, 15-79 years). Histopathologic diagnoses were chronic dacryoadenitis in 26 cases (55.32\%), IgG4-related disease in 6 patients (12.77\%), two cases of acute dacryoadenitis, two cases of non-necrotizing granulomatous inflammation, two cases of Non-Hodgkin's B-cell lymphoma, two cases of adenoid cystic carcinoma and two cases of mixed tumor ( $4.26 \%$ each), as well as one case of conjunctival epithelial cyst, and one case of benign lymphoid tissue and fibrofatty tissue (2.13\%). In two samples (4.26\%), biopsy revealed normal lacrimal glands. Interestingly, in two cases with relapsing lacrimal gland enlargement, different histopathologic diagnoses were found in biopsies taken from each lacrimal gland at different times. The average size of enlarged lacrimal glands was 19.67 $\mathrm{mm} \times 7.06 \mathrm{~mm}$ on axial CT scan and $19.44 \mathrm{~mm} \times 6.20 \mathrm{~mm}$ on coronal CT scan.

Conclusion: Tissue biopsy is needed for diagnosis of lacrimal gland enlargement because it is difficult to distinguish the type of the lacrimal gland pathology based solely on clinical or radiological presentation.

Keywords: Histopathology, IgG4-related disease, Lacrimal gland, Orbital pseudotumor

Cite this article as: Jamshidian Tehrani M, Asadi Khameneh E, Pourseyed lazarjani SZ, Ghadimi H, Nozarian Z, Mokhtari M. Clinical, radiological and histopathological features of patients with lacrimal gland enlargement. Arch Iran Med. 2021;24(12):910915. doi: 10.34172/aim.2021.136
\end{abstract}

Received: July 24, 2020, Accepted: January 12, 2021, ePublished: December 1, 2021

\section{Introduction}

The lacrimal gland is placed within a fossa of the frontal bone and produces the aqueous layer of the tear film. ${ }^{1,2}$ This gland consists of different cells such as exocrine cells, myoepithelial cells, lymphocytes, plasma cells, fibroblasts and nerve cells. ${ }^{3}$ Because of the various populations of cells present in the lacrimal gland, the enlargement of lacrimal gland may have variable differential diagnoses including infections (viral and bacterial; Epstein-Barr virus, tuberculosis, etc.), neoplasia (either primary or metastatic), inflammatory and autoimmune (sarcoidosis, Sjogren syndrome, non-specific orbital inflammation, etc.). ${ }^{1,3-7}$ The diagnosis often cannot be made based on clinical signs and symptoms; therefore, further evaluations such as imaging studies and lacrimal gland biopsy are required. ${ }^{8,9}$ To our knowledge, this is the first study in Iran in which the clinical, radiological, and histopathological features of lacrimal gland enlargement is studied.

\section{Materials and Methods}

We retrospectively retrieved the data of patients with lacrimal gland enlargement in Farabi Eye Hospital between 2012 and 2017. These data included demographics, the patients' facial photographs, orbital CT-scans, and histopathological findings of lacrimal gland biopsies.

The inclusion criteria were findings of lacrimal gland enlargement based on history and physical examination. The exclusion criteria were prior orbital surgery, history of orbital trauma and secondary involvement from known systemic malignancies. All lacrimal gland biopsies were performed by one surgeon under local anesthesia with lidocaine $2 \%$ through $5 \mathrm{~mm}$ lateral upper eyelid crease incision followed by lateral orbitotomy and obtaining biopsy from the orbital lobe of the lacrimal gland.

The study adhered to the tenets of the Declaration of Helsinki and was approved by the ethical board committee of Tehran University of medical sciences. Demographic data (including age and sex) and findings of face photographs of patients (like presence or absence of eyelid erythema) were reviewed. Additionally, the maximum length and width of lacrimal glands on the axial and coronal planes of spiral orbital CT scans with slices of 
$2 \mathrm{~mm}$ in thickness were measured with DICOM LiteBox imaging viewer (version: 3.2.0.0). Based on histopathologic reports, the final diagnoses of lacrimal gland biopsies and immunohistochemistry markers including CD138, CD3 and CD20 of specimens were recorded. A histopathologic diagnosis of IgG4-related disease was made when at least 50 IgG4-positive plasma cells were seen in high-power field light microscopy and the ratio of IgG4-positive plasma cells to IgG-positive plasma cells was more than $40 \%$. The Japanese study group criteria for diagnosis of IgG4-related disease were used as following: (1) lacrimal gland enlargement on imaging studies; (2) histopathologic features compatible with IgG4-related disease; and (3) elevated serum IgG4. According to these three criteria, IgG4-related dacryoadenitis was divided into definitive, probable and possible when patient fulfilled all three criteria, the first two criteria and the first and last criteria, respectively. ${ }^{10}$

\section{Results}

Table 1. Clinical and Demographic Characteristics of the Patients of the Current Study

\begin{tabular}{lcc}
\hline Characteristics & & No. $(\%)$ \\
\hline \multirow{2}{*}{ Gender } & Male & $15(31.91 \%)$ \\
& Female & $32(68.09 \%)$ \\
\hline \multirow{2}{*}{$\begin{array}{l}\text { Laterality based on face } \\
\text { photographs }\end{array}$} & Unilateral & $23(60.53 \%)$ \\
\cline { 2 - 3 } & Right & $16(42.11)$ \\
\hline \multirow{2}{*}{ Skin erythema of the upper lid } & Bilateral & $7(18.42 \%)$ \\
\cline { 2 - 3 } & Yes & $8(21.05 \%)$ \\
\hline
\end{tabular}

Forty-seven patients ( 15 men and 32 women) were enrolled in this study with a median age of 37.9 years (range, 1579 years). Fifteen cases had bilateral involvement and 23 cases had unilateral involvement (16 in the right eye and 7 in the left eye) based on face photographs ( 9 missing face photographs). Eight cases had eyelid erythema and 30 cases had no eyelid erythema based on face photographs (9 missing face photographs) (Table 1).

The average size of enlarged lacrimal glands was 19.67 $\mathrm{mm} \times 7.06 \mathrm{~mm}$ on axial CT scan and $19.44 \mathrm{~mm} \times 6.20$ $\mathrm{mm}$ on coronal CT scan, compared to the average normal sizes (of fellow eyes in unilateral cases) of $13.7 \mathrm{~mm} \times 4.9$ $\mathrm{mm}$ on axial CT scan and $13.9 \mathrm{~mm} \times 4.2 \mathrm{~mm}$ on coronal CT scan.

Two patients underwent bilateral lacrimal gland biopsies; thus, there were a total of 49 histologic samples. The most common histopathologic diagnoses on the first biopsy included chronic dacryoadenitis in 26 samples (55.32\%) and IgG4-related disease in 6 patients (12.77\%). Less commonly encountered pathologic entities were acute dacryoadenitis (4.26\%), non-necrotizing granulomatous inflammation (4.26\%), B-cell lymphoma (one marginal zone B-cell lymphoma and one diffuse large B-cell lymphoma) (4.26\%), two cases of adenoid cystic carcinoma and two cases of mixed tumor $(4.26 \%$ each), as well as one case of conjunctival epithelial cyst, and one case of benign lymphoid tissue and fibrofatty tissue $(2.13 \%)$. In two samples $(4.26 \%)$, the biopsy was not conclusive because it revealed normal lacrimal glands (Figure 1). The median duration of symptoms in patients with chronic dacryoadenitis, acute dacryoadenitis and IgG4-related disease was 62, 2 and 22 weeks, respectively.

Histopathologic Diagnosis

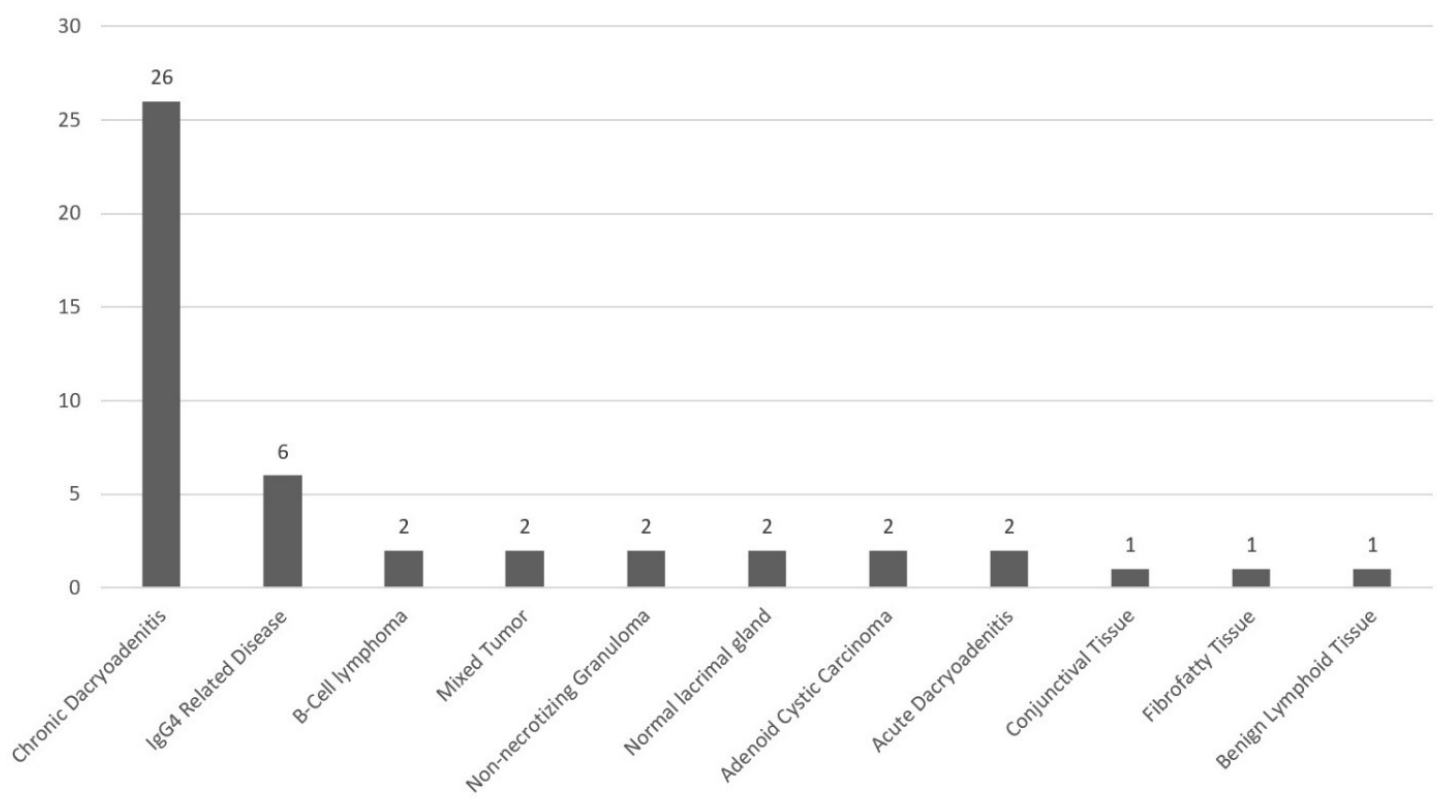


All patients with a diagnosis of chronic dacryoadenitis and IgG4-related disease had chronic onset (more than 4 weeks) except for one patient with chronic dacryoadenitis who presented with subacute onset (1-4 weeks). The initial systemic evaluation of our patients showed systemic involvement in only one patient (2.13\%).

IgG-positive cells were seen in lacrimal gland pathologic specimen of nine patients. Eight out of these nine patients also had IgG4-positive cells in lacrimal gland biopsies. Six out of eight patients, who had IgG-positive and IgG4-positive cells in pathologic specimen, met the histopathologic criteria for diagnosis of IgG4-related disease. All of these six patients fulfilled the radiologic criteria for diagnosis of IgG4-related disease. Serum IgG4 was elevated in only one of these six patients. Based on the Japanese study criteria for diagnosis of IgG4-related disease, five patients had probable and one patient had definitive IgG4-related disease.

Surprisingly, in two cases with relapsing lacrimal gland enlargement, different histopathologic diagnoses were seen in biopsies taken from each lacrimal gland at different times. One patient with systemic involvement suggesting IgG4-related disease who presented with bilateral lacrimal gland enlargement underwent right lacrimal gland biopsy; Histopathologic examinations revealed IgG4-related disease and the patient was initially treated with systemic prednisolone $(1 \mathrm{mg} / \mathrm{kg})$ and methotrexate $(7.5 \mathrm{mg} / \mathrm{wk})$. Systemic evaluation of this patient revealed positive serum antinuclear antibody (ANA), Anti-Sjögren'ssyndrome-related antigen A (anti-SSA) antibody and rheumatoid factor, subclinical hyperthyroidism, elevated serum IgG $(2922 \mathrm{mg} / \mathrm{dL})$ and serum IgG4 $(188 \mathrm{mg} / \mathrm{dL})$ and radiologic evidence of retroperitoneal fibrosis in the area of the pancreas. Roughly, 2 years later, the symptoms recurred with evidence of lacrimal gland enlargement based on physical examinations and orbital CT scan; therefore, a second biopsy was taken from the left lacrimal gland and histopathologic examination revealed chronic dacryoadenitis without evidence of IgG4-related disease (Figure 2). The second patient's first lacrimal gland biopsy was compatible with acute dacryoadenitis but after 4 years, with second biopsy taken due to recurrence of lacrimal gland enlargement, pathologic examination revealed chronic dacryoadenitis (Figure 3).

\section{Discussion}

Lacrimal gland tumors represent $5 \%$ to $35 \%$ of all orbital tumors. ${ }^{11}$ Even though most of the lesions are inflammatory, a small proportion of them are malignant neoplasms and may be life-threatening. Diagnosis of lacrimal gland pathology is not accurate based on clinical presentation solely; therefore, a tissue biopsy is often necessary. Additionally, recognition of the associations between lacrimal gland lesions and life-threatening systemic conditions, for example Granulomatosis with Polyangiitis and lymphoma, is necessary. ${ }^{11}$ In this study, we evaluated the histopathological diagnoses of enlarged

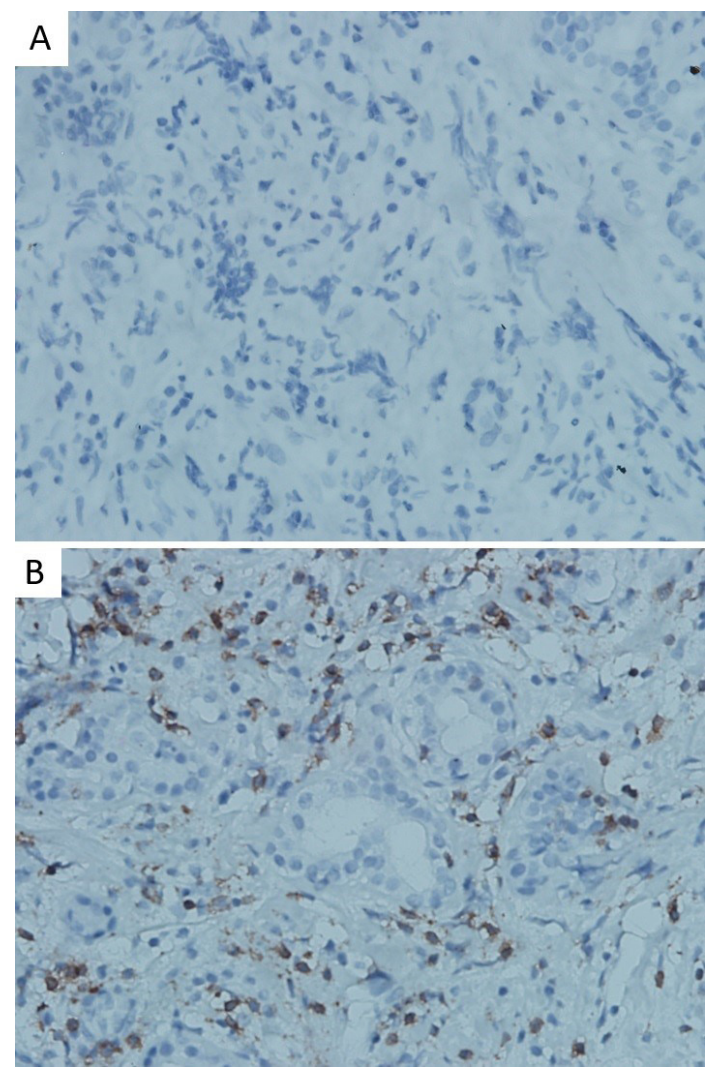

Figure 2. A: Negative IgG4 in Second Biopsy. B: Positive IgG4 in First Biopsy ( $\times 400$, Immunohistochemical staining).
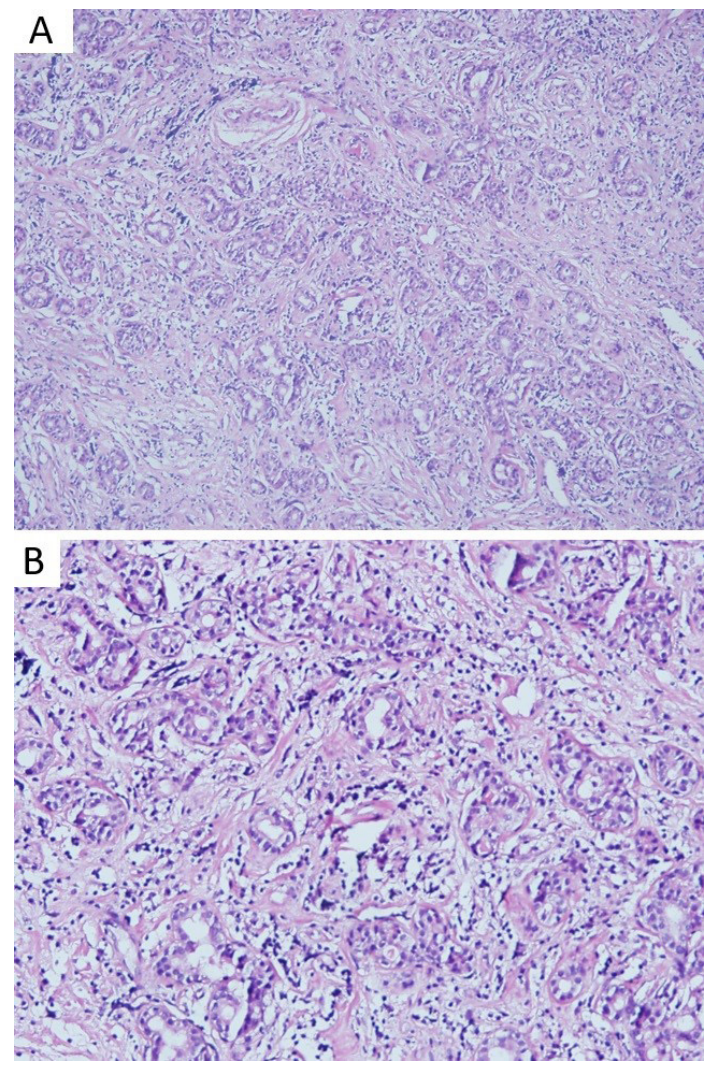

Figure 3. Chronic Dacryoadenitis. (A) Histopathologic findings show the lacrimal gland infiltrated by inflammatory cells and destruction of lacrimal gland in low power (Hematoxylin and Eosin stain, $\times 100$ ). (B) High power $(\times 200)$ shows polymorphous infiltration of chronic inflammatory cells consistent of lymphocytes, plasma cells and few eosinophils, also the lacrimal gland is also surrounded by fibrotic tissue (Hematoxylin and Eosin stain). 
lacrimal glands which were referred to a tertiary center, Farabi Eye Hospital. In our series, chronic dacryoadenitis was the most predominant pathology, followed by IgG4related disease.

In the study by Teo et al, the three most common pathologies observed in lacrimal gland biopsies were chronic dacryoadenitis (46\%), lymphoproliferative disorders (38\%) and pleomorphic adenoma (10\%). ${ }^{11}$ In comparison, they had more neoplastic cases like lymphomas and pleomorphic adenomas.

Andrew et al evaluated 268 pathologic reports of lacrimal gland biopsies and found the following prevalence of lesions: inflammation and vasculitis $50.0 \%$, lymphoma $19.8 \%$, lymphoid hyperplasia $12.3 \%$, benign epithelial

Table 2. Frequency of Lacrimal Gland Tumors in Different Published Studies

\begin{tabular}{|c|c|c|c|c|c|c|c|}
\hline \multirow{2}{*}{ Author/Date } & \multirow{2}{*}{$\begin{array}{l}\text { Follow up } \\
\text { Duration }\end{array}$} & \multirow{2}{*}{$\begin{array}{l}\text { Recurrence } \\
\text { Rate }(\%)\end{array}$} & \multirow{2}{*}{$\begin{array}{l}\text { Number } \\
\text { of Cases } \\
\text { Involving } \\
\text { Lacrimal } \\
\text { Gland }\end{array}$} & \multicolumn{2}{|l|}{$\begin{array}{l}\text { Epithelial } \\
\text { Lesion }\end{array}$} & \multicolumn{2}{|l|}{ Non-epithelial Lesion } \\
\hline & & & & Benign (\%) & Malignant (\%) & Benign (\%) & Malignant (\%) \\
\hline $\begin{array}{l}\text { Shields et al, } \\
2004^{18}\end{array}$ & 29 Months & - & 114 & $\begin{array}{l}\text { Dacryops, } \\
17 \% \\
\text { Pleomorphic } \\
\text { adenoma, } \\
10 \%\end{array}$ & Adenoid cystic carcinoma, $12 \%$ & $\begin{array}{l}\text { Dacryoadenitis, } 33 \% \\
\text { Benign lymphoid hyperplasia, } \\
6 \%\end{array}$ & $\begin{array}{l}\text { Non-Hodgkin } \\
\text { lymphoma, } 14 \%\end{array}$ \\
\hline $\begin{array}{l}\text { Günalp et al, } \\
1994^{19}\end{array}$ & - & - & 31 & $\begin{array}{l}\text { Pleomorphic } \\
\text { adenoma, } \\
42.5 \%\end{array}$ & $\begin{array}{l}\text { Adenoid cystic carcinoma, 9.4\% } \\
\text { Pleomorphic adenocarcinoma, } \\
6.4 \%\end{array}$ & Dacryoadenitis $29 \%$ & - \\
\hline $\begin{array}{l}\text { von Holstein et } \\
\text { al, } 2012^{3}\end{array}$ & - & 8.5 & 210 & $\begin{array}{l}\text { Dacryops, } \\
10.3 \% \\
\text { Pleomorphic } \\
\text { adenoma, } \\
13.4 \%\end{array}$ & $\begin{array}{l}\text { Adenoid cystic carcinoma, } 8.6 \% \\
\text { Mucoepidermoid } \\
\text { carcinoma, } 1.3 \%\end{array}$ & $\begin{array}{l}\text { Chronic dacryoadenitis, } 19 \% \\
\text { Benign lymphoid hyperplasia, } \\
4.35 \\
\text { Benign vascular tumor, } 4.3 \% \\
\text { Acute dacryoadenitis, } 3.4 \%\end{array}$ & $\begin{array}{l}\text { Malignant lymphoid } \\
\text { tumor, } 10.8 \%\end{array}$ \\
\hline $\begin{array}{l}\text { Teo et al, } \\
2013^{11}\end{array}$ & 35 Months & - & 69 & $\begin{array}{l}\text { Pleomorphic } \\
\text { adenoma, } \\
10 \%\end{array}$ & Adenoid cystic carcinoma, $1.4 \%$ & $\begin{array}{l}\text { Chronic dacryoadenitis, } 46 \% \\
\text { Lymphoproliferative disorder, } \\
38 \%\end{array}$ & - \\
\hline $\begin{array}{l}\text { Desai and } \\
\text { Shah, } 2015^{20}\end{array}$ & - & $\begin{array}{l}6.4 \% \text { in } \\
\text { patients with } \\
\text { pleomorphic } \\
\text { adenoma }\end{array}$ & 94 & $\begin{array}{l}\text { Pleomorphic } \\
\text { adenoma, } \\
65.95 \%\end{array}$ & $\begin{array}{l}\text { Adenoid cystic carcinoma, } \\
27.65 \% \\
\text { Mucoepidermoid carcinoma, } \\
3.19 \% \\
\text { Squamous cell carcinoma, } \\
1.06 \% \\
\text { Primary ductal carcinoma, } \\
1.06 \% \\
\text { Malignant pleomorphic } \\
\text { adenoma, } 1.06 \%\end{array}$ & - & - \\
\hline $\begin{array}{l}\text { Andrew et al, } \\
2015^{1}\end{array}$ & - & - & 268 & $\begin{array}{l}\text { Dacryops, } 3 \% \\
\text { Pleomorphic } \\
\text { adenoma, } \\
7.8 \%\end{array}$ & Adenoid cystic carcinoma, $2.2 \%$ & $\begin{array}{l}\text { Nonspecific dacryoadenitis, } \\
32.8 \% \\
\text { Lymphoid hyperplasia, } 12.3 \% \\
\text { IgG4-related dacryoadenitis, } \\
7.1 \% \\
\text { Sarcoidosis, } 5.2 \% \\
\text { Vasculitis, } 1.9 \% \\
\text { Bacterial infection, } 1.5 \%\end{array}$ & Lymphoma, $19.8 \%$ \\
\hline $\begin{array}{l}\text { Luemsamran et } \\
\text { al, } 2017^{5}\end{array}$ & - & $16.7 \%$ & 60 & - & - & $\begin{array}{l}\text { Nonspecific inflammation, } \\
38.3 \% \\
\text { Sjogren syndrome, } 16.6 \% \\
\text { Sarcoidosis, } 11.6 \% \\
\text { Granulomatosis with } \\
\text { polyangiitis, } 10 \% \\
\text { IgG4-related dacryoadenitis, } \\
3.3 \%\end{array}$ & Lymphoma, $8.3 \%$ \\
\hline $\begin{array}{l}\text { Priel et al, } \\
2018^{21}\end{array}$ & 13.6 Months & - & 26 & $\begin{array}{l}\text { Pleomorphic } \\
\text { adenoma, } \\
3.44 \%\end{array}$ & $\begin{array}{l}\text { Pleomorphic carcinoma, } 6.9 \% \\
\text { metastasis, } 3.44 \%\end{array}$ & $\begin{array}{l}\text { Nonspecific inflammation, } \\
44.82 \% \\
\text { Sjogren syndrome, } 3.44 \% \\
\text { Sarcoidosis, } 3.44 \% \\
\text { IgG4-related dacryoadenitis, } \\
10.34 \% \\
\text { Tuberculosis, } 3.44 \%\end{array}$ & Lymphoma, $20.68 \%$ \\
\hline $\begin{array}{l}\text { Yeşiltaş et al, } \\
2018^{22}\end{array}$ & - & $\begin{array}{l}8 \% \text { with orbital } \\
\text { inflammatory } \\
\text { lesions, } \\
21.4 \% \text { with } \\
\text { pleomorphic } \\
\text { adenoma, } \\
16.6 \% \text { with } \\
\text { adenoid cystic } \\
\text { carcinoma }\end{array}$ & 92 & $\begin{array}{l}\text { Dacryops, } \\
2.2 \% \\
\text { Pleomorphic } \\
\text { adenoma, } \\
15.2 \%\end{array}$ & Adenoid cystic carcinoma, 13\% & $\begin{array}{l}\text { dacryoadenitis, } 54.3 \% \\
\text { Benign lymphoid hyperplasia, } \\
3.3 \%\end{array}$ & Lymphoma, 5.4\% \\
\hline $\begin{array}{l}\text { Ahn et al, } \\
2019^{10}\end{array}$ & - & $\begin{array}{l}22 \% \text { in } \\
\text { patients with } \\
\text { dacryoadenitis }\end{array}$ & 95 & $\begin{array}{l}\text { Dacryops, } \\
3.2 \% \\
\text { Pleomorphic } \\
\text { adenoma, } \\
13.7 \%\end{array}$ & Adenoid cystic carcinoma, $3.2 \%$ & $\begin{array}{l}\text { Dacryoadenitis, } 31 \% \\
\text { Benign lymphoid hyperplasia, } \\
6 \% \\
\text { IgG4-related dacryoadenitis, } \\
22 \%\end{array}$ & Lymphoma, $19 \%$ \\
\hline
\end{tabular}


tumors (all pleomorphic adenomas) 7.8\%, malignant epithelial tumors $4.1 \%$, dacryops $3.0 \%$ and miscellaneous $3.0 \%{ }^{1}$ Similarly, they encountered more neoplastic cases like lymphomas and epithelial tumors.

Anotherstudy from Denmarkevaluated histopathological diagnoses among 232 lacrimal gland lesions and found half of the lesions to be neoplasms (119), 55\% of which were malignant in comparison to $23 \%$ benign tumors. Other pathologies were dacryops (10\%), inflammatory lesions (27\%) and normal tissue (12\%). ${ }^{3}$

Shields et al studied the clinicopathologic characteristics of 142 cases of lacrimal gland lesions and showed that most of the lacrimal gland lesions were of non-epithelial origin and some of them were primary epithelial neoplasms (78\% and 22\%, respectively). Most of the non-epithelial lesions were inflammation (64\%) and lymphoid tumors (14\%). The epithelial lesions included dacryops (6\%), mixed tumor (12\%), and about $4 \%$ malignant epithelial tumors were found among them. ${ }^{12}$

In a retrospective study, Luemsamran et al showed that only $23(38.3 \%)$ of 60 patients presented with inflammatory lacrimal gland signs and symptoms showing nonspecific inflammation of the lacrimal gland; however, 37 (61.7\%) had identifiable types of lacrimal inflammation (Sjogren's syndrome, sarcoidal reaction, granulomatosis with polyangiitis, sclerosing inflammation, IgG4-related dacryoadenitis, infectious dacryoadenitis, xanthogranuloma, eosinophilic angiocentric fibrosis, and eosinophilic allergic granulomatous nodule). Other pathologies were lymphoma and myoepithelial carcinoma. $^{5}$

Compared to our study, the higher percentage of malignant cases that were reported in similar studies may be due to selective biopsy of suspicious lacrimal gland lesions suggestive of potentially malignant disease unlike our study in which we performed lacrimal gland biopsy for all patients with lacrimal gland enlargement. This difference in percentage of malignant lacrimal gland lesions in our study may also be due to geographic and genetic differences between the populations of these studies. Table 2 summarizes the histopathologic diagnoses of lacrimal gland lesions in different studies.

Lacrimal gland biopsy is a minimally invasive procedure with short surgical time. It helps with better diagnosis of different diseases to avoid nonspecific empiric corticosteroid therapy. In approximately $30 \%$ to $40 \%$ of biopsy-proven IgG4-related diseases, serum IgG4 is normal and examination of serum IgG and IgG4 may not be sensitive or specific. ${ }^{13-15}$ Patients with IgG4-related disease are at higher risk of lymphoma that emphasizes the importance of biopsy in lacrimal gland lesions. ${ }^{16}$

In our study, two patients (4.25\%) had relapse of lacrimal gland enlargement after $2-4$ years. In a similar study performed by Luemsamran et al, the recurrence rate of lacrimal gland enlargement was $16.7 \% .^{5}$ The lower rate of relapse in our patients is primarily due to more cases of benign lesions in our patients and performing lacrimal gland biopsy in all patients regardless of signs and symptoms suggestive of a potentially malignant lesion. The recurrence rate varies widely across different studies; as mentioned earlier, the frequency of malignant cases, type and duration of medical treatment (especially in inflammatory lesions), presence of systemic involvement, and geographic and genetic variations across study groups could affect the recurrence rate (Table 2). In the first patient with relapse, the initial lacrimal gland biopsy revealed IgG4-related disease and the second lacrimal gland biopsy after 2 years revealed chronic dacryoadenitis. This difference in pathologic features could be due to the impact of corticosteroid drugs and methotrexate in the population of infiltrated IgG-positive and IgG4-positive plasma cells or may be due to subclass switching of IgGpositive plasma cells as mentioned by van Zelm et al. ${ }^{17}$

This study had certain limitations, including recruiting patients from a single tertiary center, a relatively small sample size and lack of IgG2 measurement in pathologic samples due to the absence of this specific laboratory kit in our center.

In conclusion, different pathological diagnoses among patients with lacrimal gland enlargement were studied and we found that tissue biopsy is needed for diagnosis of lacrimal gland enlargement because it is difficult to distinguish the type of the lacrimal gland pathology based solely on clinical or radiological presentation.

\section{Authors' Contribution}

MJT, EAK, SZPI and HG: Study design, case section, article writing. ZN and MM: Pathology slides review.

\section{Conflict of Interest Disclosures}

The authors declare no conflict of interest

\section{Ethical Statement}

There was no financial support and conflict of interests. This article was presented as a poster presentation at the XXVIII annual congress of the Iranian society of ophthalmology, November 2018, Razi convention center, Tehran-Iran and was presented as a poster presentation at the VII Meeting of Iranian Research Association for Vision and Ophthalmology, Tehran, Iran.

\section{References}

1. Andrew NH, McNab AA, Selva D. Review of 268 lacrimal gland biopsies in an Australian cohort. Clin Exp Ophthalmol. 2015;43(1):5-11. doi: 10.1111/ceo.12371.

2. Lorber M. Gross characteristics of normal human lacrimal glands. Ocul Surf. 2007;5(1):13-22. doi: 10.1016/s15420124(12)70049-6.

3. von Holstein SL, Therkildsen MH, Prause JU, Stenman G, Siersma VD, Heegaard S. Lacrimal gland lesions in Denmark between 1974 and 2007. Acta Ophthalmol. 2013;91(4):34954. doi: 10.1111/j.1755-3768.2012.02403.x.

4. Lee JS, Lee H, Kim JW, Chang M, Park M, Baek S. Computed tomographic dimensions of the lacrimal gland in healthy orbits. J Craniofac Surg. 2013;24(3):712-5. doi: 10.1097/ SCS.0b013e31827fecc0.

5. Luemsamran P, Rootman J, White VA, Nassiri N, Heran MKS. The role of biopsy in lacrimal gland inflammation: a clinicopathologic study. Orbit. 2017;36(6):411-8. doi: 10.1080/01676830.2017.1352608. 
6. Tang SX, Lim RP, Al-Dahmash S, Blaydon SM, Cho RI, Choe $\mathrm{CH}$, et al. Bilateral lacrimal gland disease: clinical features of 97 cases. Ophthalmology. 2014;121(10):2040-6. doi: 10.1016/j.ophtha.2014.04.018.

7. Wallace ZS, Deshpande V, Stone JH. Ophthalmic manifestations of IgG4-related disease: single-center experience and literature review. Semin Arthritis Rheum. 2014;43(6):806-17. doi: 10.1016/j.semarthrit.2013.11.008.

8. Bulbul E, Yazici A, Yanik B, Yazici H, Demirpolat G. Evaluation of lacrimal gland dimensions and volume in Turkish population with computed tomography. J Clin Diagn Res. 2016;10(2):TC06-8. doi: 10.7860/jcdr/2016/16331.7207.

9. Rabinowitz MP, Halfpenny CP, Bedrossian EH Jr. The frequency of granulomatous lacrimal gland inflammation as a cause of lacrimal gland enlargement in patients without a diagnosis of systemic sarcoidosis. Orbit. 2013;32(3):151-5. doi: 10.3109/01676830.2013.771676.

10. Ahn C, Kang S, Sa HS. Clinicopathologic features of biopsied lacrimal gland masses in 95 Korean patients. Graefes Arch Clin Exp Ophthalmol. 2019;257(7):1527-33. doi: 10.1007/ s00417-019-04327-w.

11. Teo L, Seah LL, Choo CT, Chee SP, Chee E, Looi A. A survey of the histopathology of lacrimal gland lesions in a tertiary referral centre. Orbit. 2013;32(1):1-7. doi: 10.3109/01676830.2012.736595.

12. Shields CL, Shields JA, Eagle RC, Rathmell JP. Clinicopathologic review of 142 cases of lacrimal gland lesions. Ophthalmology. 1989;96(4):431-5. doi: 10.1016/s0161-6420(89)32873-9.

13. Deshpande $\mathrm{V}$, Zen $\mathrm{Y}$, Chan JK, Yi EE, Sato $\mathrm{Y}$, Yoshino T, et al. Consensus statement on the pathology of IgG4-related disease. Mod Pathol. 2012;25(9):1181-92. doi: 10.1038/ modpathol.2012.72.
14. Sah RP, Chari ST. Serologic issues in IgG4-related systemic disease and autoimmune pancreatitis. Curr Opin Rheumatol. 2011;23(1):108-13. doi: 10.1097/BOR.0b013e3283413469.

15. Carruthers MN, Khosroshahi A, Augustin T, Deshpande V, Stone JH. The diagnostic utility of serum IgG4 concentrations in IgG4-related disease. Ann Rheum Dis. 2015;74(1):14-8. doi: 10.1136/annrheumdis-2013-204907.

16. Sato Y, Ohshima K, Ichimura K, Sato M, Yamadori I, Tanaka $\mathrm{T}$, et al. Ocular adnexal IgG4-related disease has uniform clinicopathology. Pathol Int. 2008;58(8):465-70. doi: 10.1111/j.1440-1827.2008.02257.x.

17. van Zelm MC. B cells take their time: sequential IgG class switching over the course of an immune response? Immunol Cell Biol. 2014;92(8):645-6. doi: 10.1038/icb.2014.48.

18. Shields JA, Shields CL, Scartozzi R. Survey of 1264 patients with orbital tumors and simulating lesions: the 2002 Montgomery Lecture, part 1. Ophthalmology. 2004;111(5):997-1008. doi: 10.1016/j.ophtha.2003.01.002.

19. Günalp I, Günduz K. Biopsy-proven orbital lesions in Turkey: a survey of 1092 cases over 30 years. Orbit. 1994;13(2):6779. doi: 10.3109/01676839409071466.

20. Desai PB, Shah A. Histopathological study of lacrimal gland tumors. Int J Res Med. 2015;4(3):50-4.

21. Priel A, Vishnevskia-Dai V, Hochma L, Gildener-Leapman J, Ben Simon GJ, Rosner M, et al. The epidemiological, clinical, and histopathological characteristics of lacrimal gland biopsies in a tertiary care center in Israel. Isr Med Assoc J. 2018;20(2):104-8.

22. Yeşiltaş YS, Gündüz AK, Erden E, Shields CL. Lacrimal gland tumors in Turkey: types, frequency, and outcomes. Int J Ophthalmol. 2018;11(8):1296-302. doi: 10.18240/ ijo.2018.08.08, 